\title{
Induction of systemic resistance and defense-related enzymes in tomato plants using Pseudomonas fluorescens CHAO and salicylic acid against root-knot nematode Meloidogyne javanica
}

\author{
Fatemeh Sarafraz Nikoo', Navazolah Sahebani ${ }^{1}$, Heshmatolah Aminian ${ }^{1}$, \\ Lachin Mokhtarnejad², Reza Ghaderi ${ }^{3 *}$
}

\begin{abstract}
${ }^{1}$ Department of Plant Protection, College of Aburaihan, University of Tehran, Tehran, 3391653755, Iran
${ }^{2}$ Department of Plant Protection, College of Agriculture, University of Tabriz, Tabriz, 5166616471, Iran

${ }^{3}$ Department of Plant Protection, College of Agriculture, Shiraz University, Shiraz, 7144165186, Iran
\end{abstract}

Received: June 1, 2014

Accepted: November 3, 2014

\begin{abstract}
Root-knot nematodes (Meloidogyne spp.) are the most economically important group of plant parasitic nematodes on many crops worldwide. Resistance-based management is considered as one of the most sound and effective strategies against these pathogens. Plant-mediated systemic resistance against the M. javanica in tomato cv. CALJN3 was triggered using salicylic acid (SA) and Pseudomonas fluorescens CHAO as elicitors. The effect of each elicitor was assayed by (1) the calculation of nematode indices including the number of nematode galls, egg masses and eggs/egg mass; (2) the analysis of changes in the concentration of reactive oxygen species (ROS); and (3) monitoring the activities of their scavenging enzymes viz. superoxide dismutase (SOD), peroxidase (POX), and catalase (CAT). The results indicated that SA/bacterial elicitors induced the removal of high concentrations of the toxic ROS via an increase in the activity of their scavenging antioxidant enzymes, especially that of catalase. Moreover, pre- or post-treatment application of the elicitors significantly reduced the number of galls, egg masses or eggs of $M$. javanica in infected tomato plants as compared to the control. The results of the present study support the involvement of the elicitor-induced ROS and related scavenging enzymes for stimulating plant defense reactions in a moderately resistant tomato challenged with M. javanica.
\end{abstract}

Key words: catalase, elicitor, hydrogen peroxide, peroxidase, reactive oxygen species, superoxide dismutase

\section{Introduction}

Root-knot nematodes are an economically important polyphagous group of highly adapted obligate plant parasites. There is a worldwide distribution of these parasites (Moens et al. 2009). Historically, recommended control practices against this group of nematodes include preplant and/or post-plant nematicide applications. However, considering environmental and human health awareness issues, alternative strategies (e.g. host plant resistance) inevitably should be investigated and implemented (Nyczepir and Thomas 2009).

Plant resistance against pathogens (e.g. plant parasitic nematodes) could be successfully induced by the biotic inducers, as well as application of different abiotic agents (Ramamoorthy et al. 2001; Branch et al. 2004; Edreva 2004; McKenry and Anwar 2007; Jagdale et al. 2009; Kone et al. 2009). Since the rhizosphere provides the first line of defense for roots against attack bysoil-borne pathogens (e.g. plant parasitic nematodes), it is generally accepted that rhizosphere bacteria are ideal biocontrol agents (HaskyGünther et al. 1998). Several studies suggest that induced systemic resistance could be one of the promising mechanisms of these bacteria for suppression of root-knot nematodes (Oostendorp and Sikora 1990; Sikora 1992; Sikora and Hoffmann-Hergarten 1992; van Loon et al. 1998; Anita et al. 2004; Siddiqui and Shaukat 2004; Bakker et al. 2007; Sikora et al. 2007). Certain strains of fluorescent pseudomonads are able to suppress plant parasitic nematodes (Sikora 1992; Santhi and Sivakumar 1995; Siddiqui et al. 2001; Anita et al. 2004; Siddiqui and Shaukat 2002, 2005), but salicylic acid does not seem to be involved in triggering the plant response against Meloidogyne javanica (Siddiqui and Shaukat 2004, 2005) or Heterodera schachtii (Siddique et al. 2014)

One of the most rapid defense responses following pathogen recognition is the so-called "oxidative burst", which constitutes the production of reactive oxygen species (ROS) such as hydrogen peroxide $\left(\mathrm{H}_{2} \mathrm{O}_{2}\right)$, superoxide anion $\left(\mathrm{O}_{2}^{-}\right)$, and hydroxyl radical $(\mathrm{OH} \cdot)$ at the site of nematode invasion (Baker and Orlandi 1995). The oxidative burst is thought to be required for several defense responses as well as for direct antimicrobial action, lignin 
formation, stiffening of cell walls, and the hypersensitive response (Mehdy 1994; Baker and Orlandi 1995; Wojtaszek 1997). Organisms protect themselves against this oxidative stress by the synthesis or inducing of various enzymatic or non-enzymatic antioxidants (Saed-Moucheshi et al. 2014). The major ROS-scavenging enzymes of plants includes superoxide dismutase (SOD), peroxidase (POX), catalase (CAT), and some other enzymatic antioxidants that are in charge in the ascorbate-glutathione cycle (Van Peer et al. 1991; Williamson and Hussey 1996; Vidhyasekaran 2002; Tománková et al. 2006; Saed-Moucheshi et al. 2014).

The interaction of root-knot nematodes with their host plants has been intensively studied and a broad range of responses from susceptibility through to resistance was established (Williamson and Hussey 1996). Several studies demonstrated the biochemical changes which resulted from these interactions (reviewed in Gheysen and Mitchum 2009; Tomczak et al. 2009), however, there is comparably little information regarding ROS and the related activity of enzymes in the infested plants with plant-parasitic nematodes. A gene encoding a catalase, which is induced after infection with rot bacteria, is induced both locally and systematically in potato infected with Meloidogyne incognita as well as Globodera pallida (Niebel et al. 1995). In tomato roots infected with root-knot nematodes, genes with homology to several known plant defense genes (including peroxidase, chitinase, lipoxygenase, and proteinase inhibitors) are induced locally within $12 \mathrm{~h}$ of inoculation (Lambert 1995). In two separate studies, SOD decreased during the initial days after inoculation, but increased dramatically in the formed galls of M. incognita on tomato roots (Zacheo and Bleve-Zacheo 1988; Vanderspool et al. 1994). An accumulation of peroxidase, phenylalanine ammonia lyase and catalase was shown in tomato root tissue treated with the Pseudomonas fluorescens isolate Pf1 in response to invasion by M. incognita (Anita et al. 2004). In a more recent study by Siddique et al. (2014), it was concluded that infection of Arabidopsis thaliana by $H$. schachtii activated the NADPH oxidases RbohD and RbohF to produce ROS, which was necessary to restrict infected plant cell death and promote nurse cell formation.

The present study was carried out to assess the induction of ROS and defense related enzymes by the $P$. fluorescens strain $\mathrm{CHAO}$ and salicylic acid (SA) against $M$. javanica in tomato as a result of induced systemic resistance.

\section{Materials and Methods}

\section{Nematode material}

Seedlings of tomato (Solanum lycopersicum L. cv. Rutgers) were selected and considered as a susceptible host for purification and for obtaining the required inoculum for the experiment. For this, the seeds were surface sterilised with $0.5 \%$ sodium hypochlorite $(\mathrm{NaOCl})$, washed three times with magnesium sulfate $\left(\mathrm{MgSO}_{4}\right) 0.1 \mathrm{M}$ and air-dried under the laminar flow. The seeds were sown in $1000-\mathrm{cm}^{3}$ pots containing steam-sterilised soil (a mix of field soil, sand, and compost at $1: 1: 2$ ratio) or perlite. Initially, the nematode was purified on the 4-6 leaf-stage transplanted tomato seedlings, by using a single egg mass (obtained from a naturally infected tomato field in Tehran). The egg masses were subsequently reproduced on tomato plants. Using an available identification key (Karssen and van Hoenselaar 1998), and taking into consideration the morphological characters of the females and juveniles, the populations were identified as M. javanica.

The nematode suspension was inoculated into clay pots containing transplanted tomato seedlings by making three $2.5 \mathrm{~cm}$ deep holes around the seedlings (Hartman and Sasser 1985; Eisenback and Triantaphyllou 1991). When large egg masses were present on the roots, the eggs were extracted by uprooting the tomato roots and rinsing the soil off the roots with tap water. Roots were dipped in $0.5 \% \mathrm{NaOCl}$ for 2 min (Hussey and Barker 1973). Then, the nematode suspension was poured onto a $74-\mu \mathrm{m}$ sieve nested on a $25-\mu \mathrm{m}$ sieve and washed with tap water to eliminate excess residues of $\mathrm{NaOCl}$. Subsequently, the eggs and second stage juveniles $\left(\mathrm{J}_{2}\right)$ were put into a beaker and their numbers estimated before using them for inoculation.

\section{Preparing the elicitors (SA and P. fluorescens CHAO)}

For preparing each liter of $10 \mathrm{mM}$ SA (Merck Co., Germany) suspension, $1.3812 \mathrm{~g}$ of SA was poured in $100 \mathrm{ml}$ of ethanol $96 \%$ and then the solution volume was diluted to $1,000 \mathrm{ml}$ by adding distilled water. Plants were inoculated with the obtained suspension by the soil-drenching method (Oka et al. 1999).

The bacterium $P$. fluorescens strain $\mathrm{CHAO}$ was cultured on suitable media such as Nutrient Agar (NA), transferred to Nutrient Broth-medium and shaken for 48 $\mathrm{h}$. The resulting suspension was centrifuged for $20 \mathrm{~min}$ at 4,500 rpm and subsequently, bacterial cell sediment was rinsed with distilled water. The bacterial concentration of the obtained suspension was justified at $10^{-9}(\mathrm{CFU} / \mathrm{ml})$ by absorbance estimation at $600 \mathrm{~nm}(\mathrm{OD}=1)$ using a spectrophotometer (Thompson 1996).

\section{Inoculation of plants with the elicitor and nematode}

Initially, the 4-6 leaf-stage transplanted tomato seedlings (cv. CALJN3) in each clay pot were inoculated with $75 \mathrm{ml}$ of SA or the bacterium suspension using the soil-drenching method. After $24 \mathrm{~h}$, nematodes were added as a $5 \mathrm{ml}$ suspension containing 2,000 eggs $+\mathrm{J} 2$, into each $230-\mathrm{cm}^{3}$ clay pot by the method discussed earlier. The pots were maintained in a greenhouse in which the greenhouse temperatures were adjusted to $27 \pm 2^{\circ} \mathrm{C}$. For defense compounds and the enzyme activity assay, the plants were laid out according to a completely randomised design with three replicates for each of the four following treatments: inoculated with either the elicitor (SA/P. fluorescens $\mathrm{CHAO}$ ) or nematode (pne); with elicitor alone (pe); with nematode alone $(p n)$; and with distilled water as the control $(p)$. For evaluatiing the nematode indices, the plants were arranged in a completely randomised design with three replicates for each of the five following treatments: plants inoculated with nematode alone $(\mathrm{N})$; plants pretreated with $\mathrm{SA} / \mathrm{P}$. fluorescens $\mathrm{CHAO}$ and after $24 \mathrm{~h}$ with 
nematode (as SN and PN, respectively), and finally, plants challenged with nematode and after $24 \mathrm{~h}$, treated with $\mathrm{SA} / P$. fluorescens $\mathrm{CHAO}$ (as NS and NP, respectively).

The number of galls and egg masses per $g$ of root was determined by cutting the roots into one $\mathrm{cm}$ long pieces from which one $g$ was randomly selected. The eggs of an egg mass were extracted by agitating the egg mass in a $0.5 \% \mathrm{NaOCl}$ solution for $2 \mathrm{~min}$ (Hussey and Barker 1973), sieved as explained earlier, and counted. The nematode indices were evaluated 50 days after inoculation.

\section{Assay of ROS levels in roots}

Hydroxyl radical $\left(\mathrm{OH}^{\cdot}\right)$ was measured according to the method described by Van Tiedemann (1997) but with slight changes. Root tissue was immersed in $1 \mathrm{ml}$ of the $1 \mathrm{mM}$ 2-deoxyribose (DOR) (sigma) as scavenger/molecular probe for $\mathrm{OH} \cdot$. The assay was incubated at the dark for $45 \mathrm{~min}$. Subsequently, a $0.5 \mathrm{ml}$ aliquot of the solution was added to a preheated mixture containing $0.5 \mathrm{ml}$ thiobarbituric acid (TBA) (Sigma) $(1 \% \mathrm{w} / \mathrm{v})$ in $0.05 \mathrm{M} \mathrm{NaOH}$ and $0.5 \mathrm{ml}$ trichloroacetic acid (TCA) (Sigma) $(2.8 \% \mathrm{w} / \mathrm{v})$. The resulting solution was immediately boiled for $10 \mathrm{~min}$. Finally, samples were cooled on ice for a further $10 \mathrm{~min}$. Absorbance was measured at $540 \mathrm{~nm}$ and the results were given as absorbance units per $\mathrm{g}$ of fresh weight (Malolepsza and Rozalska 2005).

Hydrogen peroxide $\left(\mathrm{H}_{2} \mathrm{O}_{2}\right)$ was measured using slight modifications to the method developed by Velikova et al. (2000). Root tissues $(500 \mathrm{mg})$ were homogenised in an ice bath with $5 \mathrm{ml} \mathrm{TCA}(0.1 \% \mathrm{w} / \mathrm{v})$. The homogenate was centrifuged at 12,000 $\mathrm{g}$ for $20 \mathrm{~min}$ and subsequently, a $0.5 \mathrm{ml}$ aliquot of the supernatant was added to $0.5 \mathrm{ml}$ potassium phosphate buffer $10 \mathrm{mM}$ (pH 7.0) and $1 \mathrm{ml} 1 \mathrm{M}$ potassium iodide (KI). The absorbance capability of supernatant was read at $\lambda \max =390 \mathrm{~nm}$. The measured $\mathrm{H}_{2} \mathrm{O}_{2}$ content was expressed based on $\mu \mathrm{m}$ per $\mathrm{g}$ of root tissue (Velikova et al. 2000). The concentration of ROS was assessed at $24 \mathrm{~h}$ intervals during a one week period.

\section{Assay of enzyme activity}

The SOD quantity was measured using the method (with slight modifications) developed by Patykowski and Urbanek (2003). The three $\mathrm{ml}$ reaction mixture contained $1.5 \mathrm{ml} 0.05 \mathrm{M}$ sodium phosphate buffer $(\mathrm{pH}=7.8), 0.3 \mathrm{ml}$ $130 \mathrm{mM}$ methionin, $0.3 \mathrm{ml} 750 \mu \mathrm{M}$ nitro blue tetrazolium (NBT), $0.3 \mathrm{ml} 0.1 \mathrm{mM}$ EDTA- $\mathrm{Na}_{2}, 0.3 \mathrm{ml} 20 \mu \mathrm{M}$ riboflavin, $0.01 \mathrm{ml}$ enzyme extract, $0.01 \mathrm{ml}$ polyvinyl polypyrrolidone (PVPP) $4 \%(\mathrm{w} / \mathrm{v})$, and $0.28 \mathrm{ml}$ deionized water. The reaction was started by exposing the tubes with a $30 \mathrm{~cm}$ distance under a $20 \mathrm{~W}$ fluorescent lamp for $10 \mathrm{~min}$. After covering the samples with a black cloth for $10 \mathrm{~min}$, the reduction activity of NBT was expressed as increased absorbance at $560 \mathrm{~nm} / \mathrm{h} \mathrm{g}$ of fresh weight (Patykowski and Urbanek 2003).

The activity of the peroxidase during purification, was monitored using spectrophotometric measurements of the oxidation products by guaiacol at $475 \mathrm{~nm}$ (Reuveni 1995). The reaction was performed in a $2 \mathrm{ml}$ reaction mixture containing $20 \mu \mathrm{l} 200 \mathrm{mM}$ guaiacol, extract of
$40 \mu \mathrm{g}$ protein, and buffer citrate-phosphate $(\mathrm{pH}=5.4)$. Ten $\mu \mathrm{l}$ of $\mathrm{H}_{2} \mathrm{O}_{2}(30 \% \mathrm{v} / \mathrm{v})$ was added, and finally, measurements $(475 \mathrm{~nm})$ were made at six time points with $10 \mathrm{sec}$ intervals. One unit was defined as the amount of enzyme which catalysed oxidation of $1 \mu \mathrm{mol}$ of guaiacol per min per $\mathrm{mg}$ protein at $475 \mathrm{~nm}$.

For assessing catalase activity, the reaction mixture contained $3 \mathrm{ml} 50 \mathrm{mM}$ sodium phosphate buffer $(\mathrm{pH}=$ = 7), apoplectic extract containing $30 \mu \mathrm{g}$ protein, and $30 \mathrm{ml} \mathrm{H} \mathrm{O}_{2}$. The consumption of $\mathrm{H}_{2} \mathrm{O}_{2}$ was monitored by a spectrophotometer at $240 \mathrm{~nm}$ (Sahebani 2003). The activity of enzymes was determined at $24 \mathrm{~h}$ intervals during a one week period.

\section{Statistical analysis}

Variables of the experiment were subjected to analysis of variance (ANOVA) and means were compared with Duncan's multiple range tests using SAS software. Differences at $p \leq 0.05$ were considered significant.

\section{Results}

In plants treated with salicylic acid, induction of hydroxyl radical occurred more rapidly in pn treatment when compared with the pne or pe treatments. However, during the third and fourth days after inoculation, the concentration of the hydroxyl radical was significantly higher in pne as compared to the $p n$ or pe treatments (Fig. 1A). Out of all the treatments, hydrogen peroxide increased more rapidly in plants treated with the pathogen and elicitor (pne treatment) during the first three days, but the level of hydrogen peroxide showed no significant differences during subsequent days (Fig. 1B). Salicylic acid likely has no significant effects on the induction of SOD and POX activity (Fig. 2A, B). On the other hand, SA is an effective inducer of CAT activity against invading $M$. javanica, so this enzyme activity was significantly increased in the plants treated with SA and the nematode (pne treatment), as compared with all other treatments (Fig. 2C).

In plants treated with $P$. fluorescens $\mathrm{CHAO}$, the concentration of hydroxyl radical was significantly higher in the pne treatment, as compared with the $p n$ treatment, during the first four-day period from inoculation, but showed non-significant differences during the subsequent days (Fig. 1C). The concentration of hydrogen peroxide was higher in the $p n$ treatment, the first day after inoculation, but this concentration was higher in the pne treatment during the three subsequent days (Fig. 1D). There was significantly more SOD activity in the pne than $p n$ treatment only on the third day after inoculation (Fig. 2D), but POX was significantly higher in the $p n$ treatment compared to the pne or pe treatments, during the whole experiment (Fig. 2E). Plants challenged with the bacteria and nematodes (pne treatment) showed higher levels of CAT activity when compared with the $p e, p n$ or $p$ treatments (Fig. 2F).

Both pre- or post-treatment of infected tomato seedlings with SA or P. fluorescens significantly reduced the number of galls, egg masses and eggs/egg mass of $M$. javanica as compared to the control plants (Table 1). These 
A

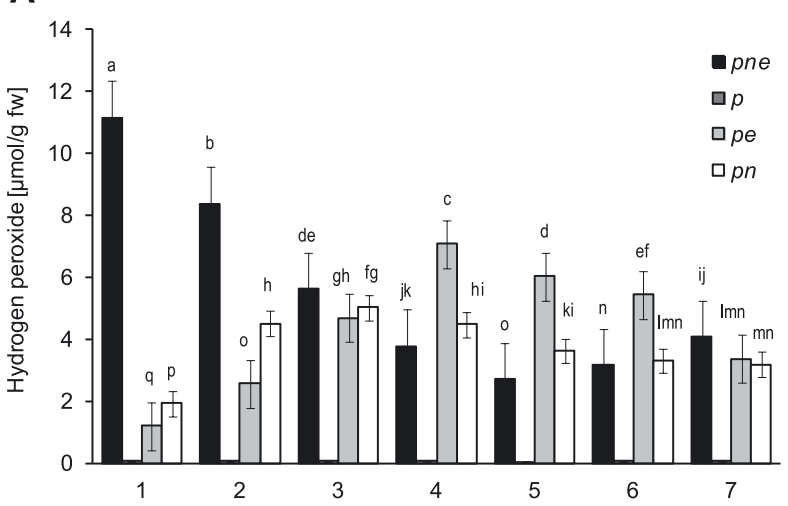

C

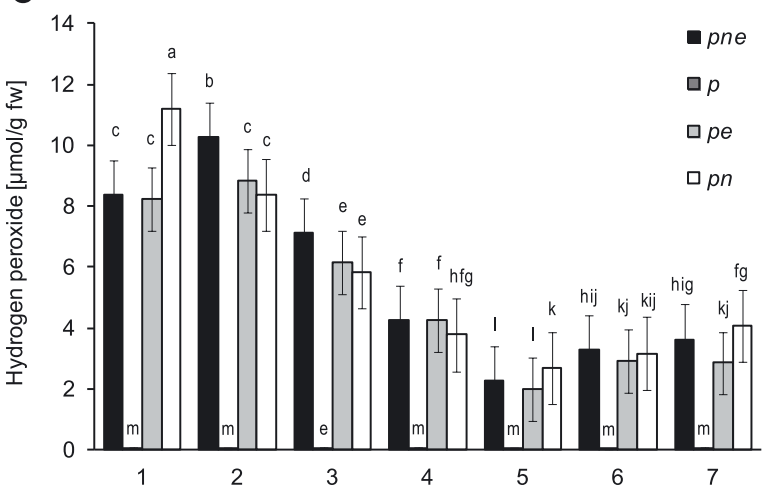

B

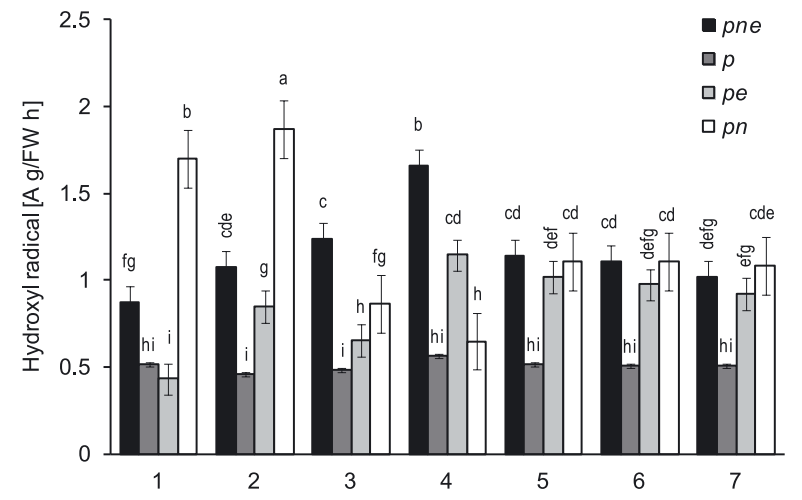

D

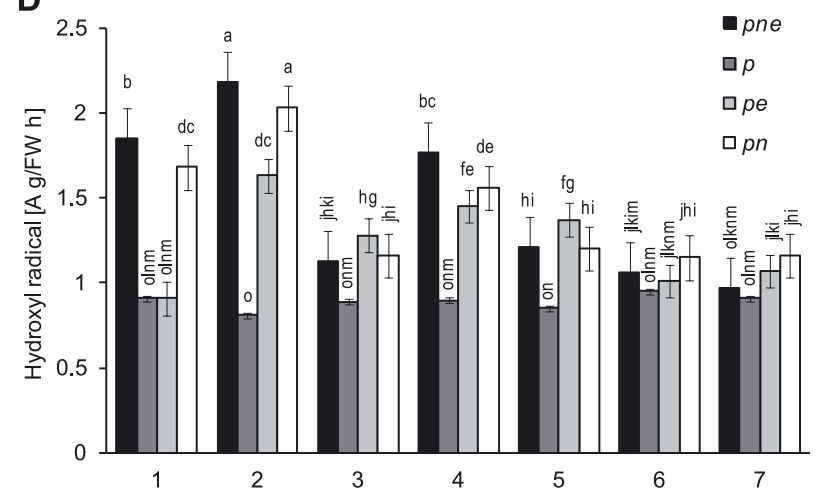

Fig. 1. Concentration of hydrogen peroxide and hydroxyl radical in the roots of tomato seedlings inoculated with either elicitor (A and B - salicylic acid; C and D - P. fluorescens CHAO) and M. javanica (pne); with distilled water, as the control treatment ( $p$ ); with elicitor alone (pe); and with $M$. javanica alone $(p n)$. Data in the horizontal lines are days after inoculation

Table 1. The number of M. javanica galls, egg masses and eggs/egg mass per each g root of tomato seedlings (cv. CALJN3), pre- or post-treated with salicylic acid (SN and NS, respectively) and P. fluorescens CHAO (PN and NP, respectively) as elicitors, 50 days after inoculation; $\mathrm{N}$ - plants inoculated with nematode alone

\begin{tabular}{lcccc}
\hline & Treatment/character & Gall* & Egg mass & Eggs/egg mass \\
\hline The control & $\mathrm{N}$ & $208.3 \mathrm{a}$ & $262.3 \mathrm{a}$ & $362.3 \mathrm{a}$ \\
\hline Pre-treatment & $\mathrm{SN}$ & $65.7 \mathrm{c}$ & $30.7 \mathrm{c}$ & $87.0 \mathrm{~d}$ \\
& $\mathrm{PN}$ & $47.3 \mathrm{~cd}$ & $45.0 \mathrm{c}$ & $161.7 \mathrm{c}$ \\
\hline Post-treatment & NS & $22.0 \mathrm{~d}$ & $20.0 \mathrm{c}$ & $261.7 \mathrm{~b}$ \\
& $\mathrm{NP}$ & $105.0 \mathrm{~b}$ & $95.7 \mathrm{~b}$ & $280.0 \mathrm{~b}$ \\
\hline
\end{tabular}

*within a column, averages sharing a letter are not significantly different at $\mathrm{p} \leq 0.05$ according to Duncan's multiple range test

controlling effects were more evident in the pre-treatment than in the post-treatment application of P. fluorescens (for all three indices) or SA (only for eggs/egg mass).

\section{Discussion}

The SA/bacterial elicitor-mediated generation of ROS and the subsequent activities of the related antioxidant enzymes were examined in an attempt to determine their roles in the resistance reactions of tomato seedlings to infection with M. javanica.
Exogenous application of SA and P. fluorescens $\mathrm{CHAO}$ significantly reduced the root-knot nematode population in tomato roots. Root galling and egg mass/egg production in tomato due to infestation by $M$. javanica was also less in plants treated with both elicitors. This is in agreement with the works using $P$. fluorescens as elicitor against M. incognita (Santhi and Sivakumar 1995; Anita et al. 2004). The present study revealed a significant accumulation of CAT, but that of SOD or POX did not followed similar trends. The accumulation of CAT began on the first day after inoculation with the nematode and the accumulation gradually increased for up to three 
A

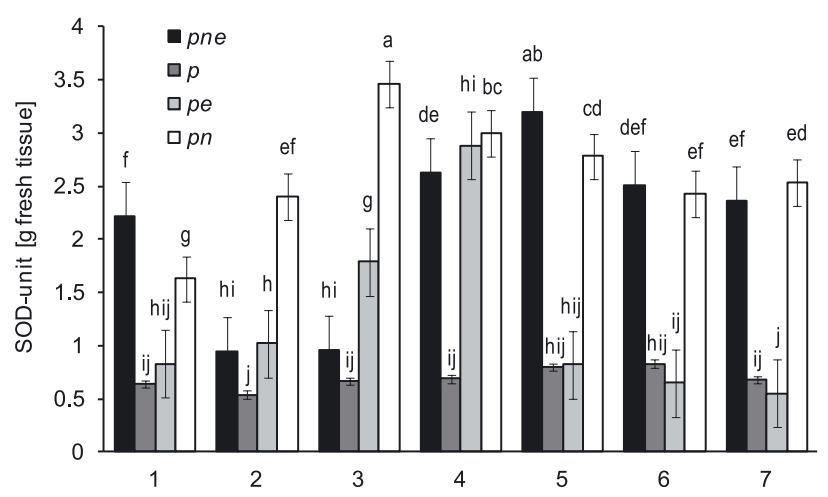

C
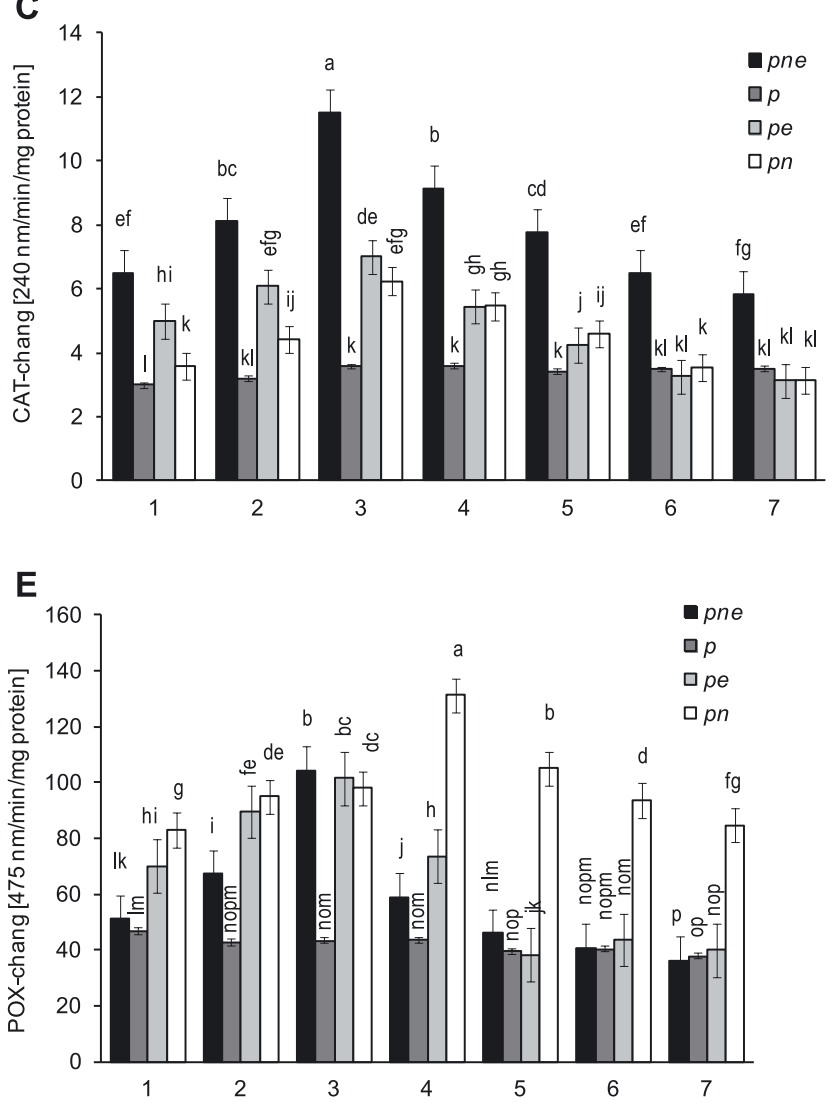

B

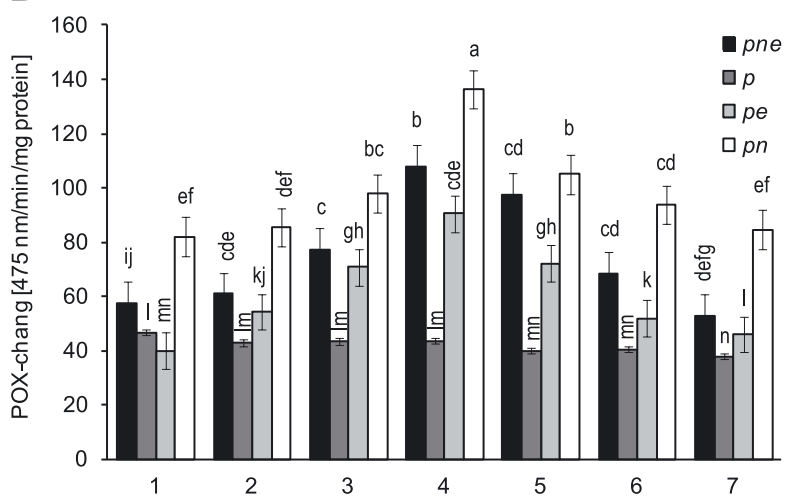

D

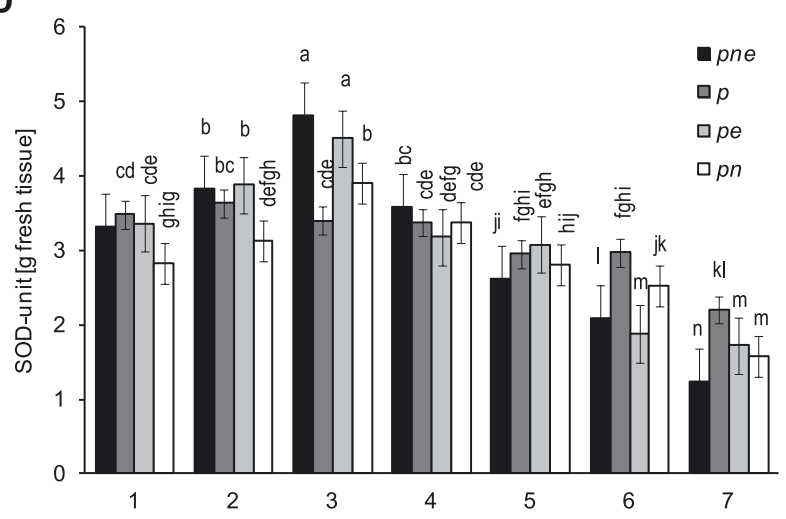

$\mathbf{F}$

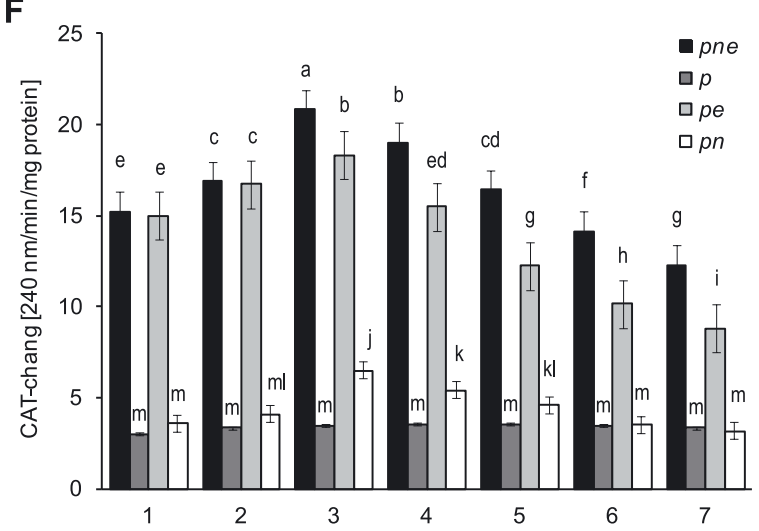

Fig. 2. Activity of superoxide dismutase (SOD), peroxidase (POX) and catalase (CAT) in the roots of tomato seedlings inoculated with either elicitor (A-C - salicylic acid; D-F - P. fluorescens CHAO) and M. javanica (pne); with distilled water, as the control treatment $(p)$; with elicitor alone (pe); and with $M$. javanica alone ( $p n)$. Data in the horizontal lines are days after inoculation

days and then subsequently decreased till seven days after inoculation. Plants inoculated with the elicitor alone (pe treatment) or nematode alone ( $p n$ treatment) also showed an increased CAT level, but the increases were less than in the pne treatment. It may be concluded, that high levels of $\mathrm{H}_{2} \mathrm{O}_{2}$ in the root tissue and an increase activity of CAT at the beginning of infection may be needed to inhibit infection, but the activity of SOD or POX may not play very important roles in elicitor-mediated resistance in tomato cv. CALJN3 to M. javanica.

While investigating the resistance of tomato plant cultivars toward infection with $M$. incognita, Zacheo and Bleve-Zacheo (1988) reported a fall of SOD activity in hypersensitively responding tomato plants. Similar results were obtained by Vanderspool et al. (1994) who confirmed a decline in the activity of SOD in resistant soybean, $96 \mathrm{~h}$ after nematode infection. In contrast, SOD increased dramatically in galls (Zacheo and Bleve-Zacheo 1988 ) or as nematodes matured and enlarged (Vanderspool et al. 1994). There might be an involvement of SOD in processes related to the development and maintenance of the nematode feeding sites and this involvement might provide protection against superoxide-mediated damage in a compatible response. It appears, that generation of superoxide radicals is an important feature of the local events that occur in an incompatible interaction, while an increased scavenging activity of superoxide onions by SOD, with concurrent production of $\mathrm{H}_{2} \mathrm{O}_{2}$ occurs in a compatible interaction. Clearance of $\mathrm{H}_{2} \mathrm{O}_{2}$ may be a sub- 
sequent defensive step that could be induced by the action of POX or CAT (Zacheo et al. 1997).

In our experiment, the concentration of $\mathrm{H}_{2} \mathrm{O}_{2}$ was increased rapidly the first and second days after inoculation, and subsequently, CAT activity increased three days after inoculation. It is supposed that the scavenging activity of CAT corresponds to the rapidity and intensity of $\mathrm{H}_{2} \mathrm{O}_{2}$ production. It was well established that CAT might be responsible for the removal of the excess of ROS during stress (Mittler 2002). However, the significant increase in CAT activity in the present study differs from the hardly distinguishable increase of this enzyme in tomato plants challenged with M. incognita (Rajasekhar et al. 1997; Anita et al. 2004). These differences in enzyme activity may be attributed to the resistance level of the challenged host plants (Zacheo et al. 1995; Rajasekhar et al. 1997; Tománková et al. 2006). Tománková et al. (2006) found that CAT activity differs among susceptible, moderately resistant, and highly resistant varieties of tomato plants against Oidium neolycopersici (the cause of powdery mildew), so activity of this enzyme showed higher accumulation in moderately resistant tomato. Zacheo et al. (1995) pointed out that there is a relationship between the activity of antioxidant enzymes and the resistance level of the host plants. It already has been shown that tomato cv. CALJN3 could be considered as a moderately resistant host for M. javanica (Maleki Ziarati 2006).

The present study revealed the involvement of elicitor-mediated induction of ROS and the scavenging enzymes in a resistant host plant (tomato cv. CALJN3) challenged with $M$. javanica. Further studies dealing other nematode species or different levels of resistance during a longer time period, are suggested. Such studies can provide for a better understanding of the potential contribution of ROS and antioxidant enzymes in the defense mechanisms of plants during compatible or incompatible interactions against plant-parasitic nematodes.

\section{Acknowledgements}

The authors are grateful to Mrs. Shina Zaman for her help with the statistical analysis of the data. The project was financially supported by the College of Aburaihan, Tehran University, Tehran (Iran).

\section{References}

Anita B., Rajendran G., Samiyappan R. 2004. Induction of systemic resistance in tomato against root-knot nematode, Meloidogyne incognita by Pseudomonas fluorescens. Nematol. Medit. 32 (1): 47-51.

Baker C.J., Orlandi E.W. 1995. Active oxygen in plant pathogenesis. Annu. Rev. of Phytopathol. 33: 299-321.

Bakker P.A.H.M., Pieterse C.M.J., van Loon L.C. 2007. Induced systemic resistance by fluorescent Pseudomonas spp. Phytopathology 97 (2): 239-243.

Branch C., Hwang C.F., Navare D.A., Williamson V.M. 2004. Salicylic acid is part of the Mi-1-mediated defense response to root-knot nematode in tomato. Mol. Plant Microbe Interact. 17 (4): 351-356.
Edreva A. 2004. A novel strategy for plant protection: Induced resistance. J. Cell Mol. Biol. 3 (1): 61-69.

Eisenback J.D., Triantaphyllou A.C. 1991. Root-knot nematodes: Meloidogyne species and races. p. 191-274. In: “Manual of Agricultural Nematology" (W.R. Nickle, ed.). Marcel Dekker, Inc., New York, USA, 1035 pp.

Gheysen G., Mitchum G. 2009. Molecular insights in the susceptible plant response to nematode infection. p. 45-82. In: "Cell Biology of Plant Nematode Parasitism" (R.H. Berg, C.G. Taylor, eds.). Springer-Verlag, Berlin Heidelberg, Germany, 273 pp.

Hartman K.M., Sasser J.N. 1985. Identification of Meloidogyne species on the basis of differential host test and perinealpattern morphology. p. 69-77. In: "An Advanced Treatise on Meloidogyne. Vol. 2. Methodology" (K.R. Barker, C.C. Carter, J.N. Sasser, eds.). North Carolina State University Graphics, Raleigh, USA, 223 pp.

Hasky-Günther K., Hoffmann-Hergarten S., Sikora R.A. 1998. Resistance against the potato cyst nematode Globodera pallida systemically induced by the rhizobacteria Agrobacterium radiobacter (G12) and Bacillus sphaericus (B43). Fundam. Appl. Nematol. 21 (5): 511-517.

Hussey R.S., Barker K. 1973. A comparison of methods of collecting inocula of Meloidogyne spp., including a new technique. Plant Dis. Rep. 57: 1025-1028.

Jagdale G.B., Kamoun S., Grewal P.S. 2009. Entomopathogenic nematodes induce components of systemic resistance in plants: biochemical and molecular evidence. Biol. Control 51 (1): 102-109.

Karssen G., Van Hoenselaar T. 1998. Revision of the genus Meloidogyne Göldi, 1892 (Nematoda: Heteroderidae) in Europe. Nematologica 44: 713-788.

Kone D., Csinos A.S., Jackson K.L., Ji P. 2009. Evaluation of systemic acquired resistance inducers for control of Phytophthora capsici on squash. Crop Prot. 28 (6): 533-538.

Lambert K.N. 1995. Isolation of genes induced early in the resistance response to Meloidogyne javanica in Lycopersicon esculentum. Ph.D. thesis, University of California, Davis, USA, $180 \mathrm{pp}$.

Maleki Ziarati H. 2006. Biological control of the root-knot nematode, Meloidogyne javanica, by Trichoderma harzianum in tomato plants and detection of the some plant biochemical defense mechanisms. M.Sc. thesis. College of Aburaihan, Tehran University, Tehran, Iran, 120 pp.

Malolepsza U., Rozalska S. 2005. Nitric oxide and hydrogen peroxide in tomato resistance, nitric oxide modulates hydrogen peroxide level in $o$-hydroxyethylorutin-induced resistance to Botrytis cinerea in tomato. Plant Physiol. Biochem. 43 (1): 623-635.

McKenry M.V., Anwar S.A. 2007. Virulence of Meloidogyne spp. and induced resistance in grape rootstocks. J. Nematol. 39 (1): 50-54.

Mehdy M.C. 1994. Active oxygen species in plant defense against pathogens. Plant Physiol. 105 (2): 467-472.

Mittler R. 2002. Oxidative stress, antioxidants and stress tolerance. Trends Plant Sci. 7 (9): 405-410.

Moens M., Perry R.N., Starr J.L. 2009. Meloidogyne speciesa diverse group of novel and important plant parasites. p. 1-17. In: “Root-Knot Nematodes" (R.N. Perry, M. Moens, J.L. Starr, eds.). CABI Publishing, Wallingford, Oxon, UK, $488 \mathrm{pp}$ 
Niebel A., Heungens K., Barthels N., Inzé D., Van Montagu M., Gheysen G. 1995. Characterization of a pathogen-induced potato catalase and its systemic expression upon nematode and bacterial infection. Mol. Plant Microbe Interact. 8 (3): 371-378.

Nyczepir A.P., Thomas S.H. 2009. Current and future management strategies in intensive crop production systems. p. 412-443. In: "Root-Knot Nematodes" (R.N. Perry, M. Moens, J.L. Starr, eds.). CABI Publishing, Wallingford, Oxon, UK, 488 pp.

Oka Y., Cohen Y., Speigel Y. 1999. Local and systemic induced resistance to the root-knot tomato by DL- $\beta$-amino-n-butyric acid. Phytopathology 89 (12): 1138-1143.

Oostendorp M., Sikora R.A. 1990. In vitro relationship between rhizosphere bacteria and Heterodera schachtii. Revue de Nematologie 13 (3): 269-274.

Patykowski J., Urbanek H. 2003. Activity of enzymes related to $\mathrm{H}_{2} \mathrm{O}_{2}$ generation and metabolism in leaf apoplastic fraction of tomato leaves infected with Botrytis cinerea. J. Phytopathol. 151 (3): 153-161.

Rajasekhar S.P., Ganguly A.K., Swain S.C. 1997. Quantitative changes in superoxide dismutase catalase and peroxidase with reference to resistance in tomato to Meloidogyne incognita. Indian J. Nematol. 27 (1): 79-85.

Ramamoorthy V., Viswanathan R., Raguchander T., Prakasam V., Samiyappan R. 2001. Induction of systemic resistance by plant growth promoting rhizobacteria in crop plants against pests and diseases. Crop Prot. 20 (1): 1-11.

Reuveni R. 1995. Biochemical markers as tools for screening resistance against plant pathogens. p. 21-42. In: "Noval Approaches to Integrated Pest Management" (R. Reuveni, ed.). CRC Press, Boca Raton, USA, 384 pp.

Saed-Moucheshi A., Pakniyat H., Pirasteh-Anosheh H., Azooz M.M. 2014. Role of ROS as signaling molecules in plants. p. 585-626. In: "Reactive Oxygen Species, Antioxidant Network and Signaling in Plants" (P. Ahmad, ed.). Springer Publication, New York, USA, 635 pp.

Santhi A., Sivakumar V. 1995. Biocontrol potential of Pseudomonas fluorescens (Migula) against root-knot nematode, Meloidogyne incognita (Kofoid and White, 1919) Chitwood, 1949 on tomato. J. Biol. Control 9: 113-115.

Siddiqui I.A., Shaukat S.S. 2002. Rhizobacteria-mediated induction of systemic resistance (ISR) in tomato against Meloidogyne javanica. J. Phytopathol. 150 (8-9): 469-473.

Siddiqui I.A., Shaukat S.S. 2004. Systemic resistance in tomato induced by biocontrol bacteria against the root-knot nematode, Meloidogyne javanica is independent of salicylic acid production. J. Phytopathol. 152 (1): 48-54.

Siddiqui I.A., Shaukat S.S. 2005. Pseudomonas aeruginosa-mediated induction of systemic resistance in tomato against rootknot nematode. Plant Pathol. J. 4 (1): 21-25.

Siddiqui I.A. Ehteshamul-Haque S., Shaukat S.S. 2001. Use of rhizobacteria in the control of root rot-root knot disease complex of mungbean. J. Phytopathol. 149 (6): 337-346.

Siddique S., Matera C., Radakovic Z.S., Shamim Hasan M., Gutbrod P., Rozanska E., Sobczak M., Torres M.A., Grundler F.M.W. 2014. Parasitic worms stimulate host $\mathrm{NADPH}$ oxidases to produce reactive oxygen species that limit plant cell death and promote infection. Sci. Signal. 7 (320): 1-9.
Sikora R.A. 1992. Management of the antagonistic potential in agricultural ecosystems for the biological control of plant parasitic nematodes. Annu. Rev. Phytopathol. 30: 245-270.

Sikora R.A., Hoffmann-Hergarten S. 1992. Importance of plant health-promoting rhizobacteria for the control of soilborne fungal diseases and plant parasitic nematodes. Arab. J. Plant Prot. 10: 53-58.

Sikora R.A., Schäfer K., Debabat A.A. 2007. Mode of action associated with microbially induced in planta suppression of plantparasitic nematodes. Australas. Plant Pathol. 36 (1): 124-134.

Thompson D.C. 1996. Evaluation of bacterial antagonists for reduction of summer patch symptoms in Kentucky blue grass. Plant Dis. 80 (8): 850-862.

Tománková K., Luhová L., Petřivalsky M., Peč P., Lebeda A. 2006. Biochemical aspects of reactive oxygen species formation in the interaction between Lycopersicon spp. and Oidium neolycopersici. Physiol. Mol. Plant Pathol. 68 (1-3): 1-11.

Tomczak A., Koropacka K., Smant G., Goverse A., Bakker E. 2009. Resistant plant responses. p. 83-114. In: "Cell Biology of Plant Nematode Parasitism" (R.H. Berg, C.G. Taylor, eds.). Springer-Verlag, Berlin Heidelberg, Germany, 273 pp.

Van Loon L.C., Bakker P.A.H.M., Pieterse C.M.J. 1998. Systemic resistance induced by rhizosphere bacteria. Annu. Rev. Phytopathol. 36: 453-483.

Van Peer R., Niemann G.J., Schippers B. 1991. Induced resistance and phytoalexin accumulation in biological control of $\mathrm{Fu}$ sarium wilt of carnation by Pseudomonas sp. strain WCS 417r. Phytopathology 81 (7): 728-734.

Von Tiedemann A. 1997. Evidence for a primary role of active oxygen species in induction of host cell death during infection of bean leaves with Botrytis cinerea. Physiol. Mol. Plant Pathol. 50: 151-166.

Vanderspool M.C., Kaplan D.T., McCollum T.G., Wodzinski R.J. 1994. Partial characterization of cytosolic superoxide dismutase activity in the interaction of Meloidogyne incognita with two cultivars of Glycine max. J. Nematol. 26 (4): 422-429.

Velikova V., Yordanov I., Edreva A. 2000. Oxidative stress and some antioxidant systems in acid rain-treated bean plants, protective role of exogenous polyamines. Plant Sci. 151 (1): 59-66.

Vidhyasekaran P. 2002. Bacterial Disease Resistance in Plants, Molecular Biology and Biotechnological Applications. Food Products Press, New York, USA, 452 pp.

Williamson V.M., Hussey R.S. 1996. Nematode pathogenesis and resistance in plants. Plant Cell 8 (10): 1735-1745.

Wojtaszek P. 1997. Oxidative burst: an early plant response to pathogen infection. Biochem. J. 322 (3): 681-692.

Zacheo G., Bleve-Zacheo T. 1988. Involement of superoxide dismutases and superoxide radicals in the susceptibility and resistance of tomato plants to Meloidogyne incognita attack. Physiol. Mol. Plant Pathol. 32 (2): 313-322.

Zacheo G., Bleve-Zacheo T., Pacoda D., Orlando C., Durbin R.D. 1995. The association between heat-induced susceptibility of tomato to Meloidogyne incognita and peroxidase activity. Physiol. Mol. Plant Pathol. 46 (6): 491-507.

Zacheo G., Bleve-Zacheo T., Melillo M.T. 1997. Biochemistry of plant defence responses to nematode infection. p. 201-213. In: "Cellular and Molecular Aspects of Plant-Nematode Interactions" (C. Fenoll, F.M.W. Grundler, S.A. Ohl, eds.). Kluwer Academic Publishers, The Netherlands, 288 pp. 